\title{
Research Square \\ Assessing the Determinants of Electricity Generation Infrastructure in Nigeria
}

lyabo Olanrele ( $\nabla$ adeyemiyabo@yahoo.com )

Nigerian Institute of Social and Economic Research

\section{Research}

Keywords: Electricity infrastructure, Development, Macroeconomic variables, Nigeria

Posted Date: November 22nd, 2021

DOI: https://doi.org/10.21203/rs.3.rs-1053573/v1

License: (9) This work is licensed under a Creative Commons Attribution 4.0 International License. Read Full License 


\section{Abstract}

The supply and demand for electricity have outpaced available infrastructure in Nigeria despite the abundant energy resources. The paper investigates the determinants of electricity generating infrastructure in Nigeria for the period 1980 to 2016. Using an Autoregressive Distributed Lag model, electricity generation capacity was used as an indicator for electricity infrastructure development. Its expansion was based on the behaviour of inflation rate, total government expenditure, interest rate, private sector financial credit, exchange rate, real GDP per capita, real gross fixed capital formation, and the rate of urbanisation. Financial credit to private sector, total public expenditure, real per capita income, real gross fixed capital formation, urbanization, and exchange rate adversely affect the development of electricity generation capacity. Investment in generating assets is capital intensive, which should be matched with adequate private sector financing. If the power sector subsidy will remain and achieve its objective, strategies that will lead to sustaining exchange rate stability should be promoted. Based on estimate, every one million population require $1000 \mathrm{MW}$ of electricity to function in modern-day society implying that Nigeria needs $180,000 \mathrm{MW}$ of electricity capacity. The realisation of this is hinged on large scale electricity infrastructure investment enabled, partly, by the favourable macroeconomic environment.

JEL Classification: E16, 01, 02

\section{Introduction}

The supply and demand for electricity have outpaced available infrastructure in Nigeria. With the abundant energy resources-hydro, fuel and renewable-huge infrastructural gap exist in the electricity market, evident in the margins between generating capacity and actual demand. The provision of infrastructure engenders shift from low growth equilibrium to a high growth steady state (Calderon \& Serven, 2010; Agenor \& Neanidis, 2015). In developed economies, the provision of infrastructure provides a variety of critical services that help determine economy's production and consumption possibilities (Aschauer, 1998; Mentolio et. al., 2008; Sole-Olle, 2009; Palei, 2015). Adequate and efficient infrastructure also serves as a conduit for capital inflows, which equally impact on economic growth and development (Snieska \& Draksaite, 2007; Martinkus \& Lukasevicius, 2008 Calderon \& Serven, 2014). In Nigeria's context, the huge investment gap in electricity infrastructure will continue to inhibit wider access and growth opportunities.

Development in electricity generation infrastructure dates back to 1886 when two generating sets were installed (NESI, 2019). Much investment has not been realised in the electricity generation value chain decades after. Available installed electricity generation capacity stands at about 12,500 Megawatts (MW), amounting to about 532 percent in 1980 to 2017. At this rate, electricity generation cannot match Africa's most populous country electricity demand. It was estimated that about 28,000MW, 51,000MW, and $77,000 \mathrm{MW}$ will be required to engender a 7 percent economic growth in 2015, 2020, and 2025 respectively (Sambo, 2008). At present, the total installed capacity of existing electricity generating plants in Nigeria, 
at about $12,500 \mathrm{MW}$, lags behind the projection for 2015, and three times lower than the 2020 requirement.

The various power sector reforms have not brought many improvements in the development of power sector infrastructure in the country. An example is the recent power sector privatisation of 2013 that has not yielded much success different from when the sector was under state control. Pre the power sector privatisation era, 2012 , the total electricity generation installed capacity was $5603 \mathrm{MW}$. This increase to about $12,500 \mathrm{MW}$ in the post-privatisation period. This situation has grave implication in ensuring universal access to electricity, one of the focal point of Sustainable Development Goals (SDG-7). Of the over 180 million population, about 42 percent lack electricity access in 2016 with a difference across urban and rural locations (World Development Indicators, 2017). The urban access to electricity (78.4\%) exceeds what obtains in the rural area (39.3\%). These scenarios if not matched with the required infrastructural investment will continue to stifle growth and development.

In the modern-day societies, sustain efforts towards economic, social, and institutional factors bolster electricity infrastructural development. The case tends to be different in developing countries, like Nigeria, if one considers the performance of the macroeconomy that is largely characterised by frequent instability. The literature identifies macroeconomic aggregates like per capita GDP, interest rate, inflation rate, debt, fiscal expenditure, resource endowment, tax rate/incentives, among others, as factors affecting general investment decision even on infrastructure (Nwanwko, 2006, Akinlo et.al. 2013, Agénor, et al., 2015, Cerra, et.al, 2016). Unfortunately, the macroeconomic environment has kept at bay the needed infrastructural development. In the period 1980 to 2017, the inflation rate was at double-digit reaching as much as 17.3 percent, the interest rate was about 19.1 percent, while financial credit to the private sector as a share of GDP was around 15 percent. In addition, the average GDP per capita in the referenced period at about US\$1748 shows a low level of development, which is postulated to have a direct relationship with the quality of infrastructure (Goes, 2016). Apparently, the harsh investment climate, institutional inefficiencies, lack of political will, amongst others, attributed to the country's lack of investment in electricity infrastructure.

To proactively cope with the increasing electricity demand that will drive economic growth, it is important to examine the determinants of generation infrastructure. Close to this study in the literature are the studies that focused on the growth effect of infrastructural development. For instance, Peprah (2015), examined the determinants of electricity generation in 25 sub-Saharan African countries. Privatisation, labour, and GDP per capita exert a positive effect on electricity generation. However, regulatory quality has an insignificant effect on electricity generation. Considering the relationship between infrastructure and economic growth in sub-Sahara Africa, Kondogo \& Ojah (2016) found that spending on infrastructure and increments in the access to infrastructure influence economic growth and development in SubSaharan Africa. Other strands of literature investigated the determinants of electricity supply in Nigeria, (Ubi et. al., 2012,). The instances above do not consider the need for expanding the existing electricity supply capacity which is the crux of this study. 
The growing dynamics in the country, in terms of population growth and the need for urgent development, makes it germane to accelerate infrastructural expansion in the electricity generation value chain. Also, access to energy is one of the central objectives of the sustainable development goals, which could be facilitated with an increase in electricity generation capacity. The emphasis in this paper is to identify those economic factors that require urgent attention in boosting the optimal performance of the electricity generation value chain for enhance electricity access, ultimately economic growth and development. In assessing the determinants of electricity generation infrastructure, the linear Autoregressive Distributed Lag (ARDL) model is employed since it provides a means of examining short and long-run scenarios. Annual data from 1980 to 2017 is employed. The outcome from the study was utilised to derive policy prescriptions towards increasing electricity access for sustainable development.

The remainder of the paper is structured as follows: section two, an overview of electricity infrastructure in Nigeria. Section three dwells on the review of relevant literature. Section four provides detail on the methodology and data used, Section five presents and discuss the empirical results, while the last section concludes with some recommendation.

\section{Electricity Generation Infrastructure In Nigeria}

The paper assessed the determinants of electricity infrastructure, with a particular interest in the electricity generation sub-sector. Hence the emphasis in this section is on the electricity generation infrastructure.

Electricity generation dates back to 1886 with two generating sets (NESI, 2019). At present, the generating sub-sector has twenty-three power plants connected to the central grid. The mix comprised the recently privatised generation plants, Independent Power Plants (IPPs), the National Integrated Power Plants Projects (NIPP). The total installed capacity of these power plants stands at about 10,396MW (NESI, 2019). Thermal-based generating plants have $8,457.6 \mathrm{MW}$ (81.4\%) and hydro plants $1,938 \mathrm{MW}(18.6 \%)$ installed capacity respectively. On the average, the stock of power infrastructure, electricity generation installed capacity has grown steadily in the period 1980 to 2017 (Figure 1). However, this lagged far behind Nigeria's population growth, which has increased significantly over the years.

Beyond this, the gains of electricity generation in Nigeria, in terms of access, has not competed favourably among the top five economies in Africa (Figure 2a). The North African countries (Algeria, and Morocco) have witnessed a marked improvement in electricity infrastructure development, which is mirrored in the proportion of the population with access to electricity. It is a different case entirely in the sub-Saharan African region, even as oil-rich economies (Nigeria and Angola) struggle to consolidate oil benefits into infrastructural development. Except for South Africa, neither Nigeria nor Angola could meet its total population electricity demand, which is below 50 percent in the period 1990 to 2016 (Fig 2a). A disparity exists between urban and rural electricity access in Nigeria, with access in the urban area higher than 40 percent rural access (Fig 2b). This has implication for the existing rural electrification strategy, hence, viable financing options supported by a strong macroeconomic environment has to be considered 
in enhancing rural transformation agenda in the country. Although Nigeria's electricity generation capacity is low, another major challenge is that the final electricity supply has constantly been constraint by high distribution and transmission losses (Fig 3).

\section{Literature Review}

This section deals with a review of relevant literature. The early part of the section discusses the general determinants of infrastructure development, while the remaining part narrowed the review to electricity generation infrastructure and its determinants.

A study by Cerra, et. al. (2017) examined the factors that affect the stock of infrastructure and it's financing across the world. The authors used a dynamic panel of 110 countries (advanced Europe, Canada, and the United States, emerging Asia, LAC, and sub-Saharan Africa) during 1990-2013. Findings from the study revealed that public finance and private sector participation both contribute to improving the stock of infrastructure. Also, the impact of public finance depends on how a capital investment is financed to meet the government's budget constraint. Total domestic finance of infrastructure depends, in turn, on domestic financial depth and links to the rest of the world through trade and foreign investment.

Jedwab \& Storeygard (2017) examined the economic and political factors of infrastructure investment. The study centers on the evolution of road stock in 43 sub-Saharan Africa using data from 1960 to 2015. The results of the investigation show a strong relationship between transportation investments and economic development. Other non-economic factors like the pre-colonial centralization, ethnic fractionalization, European settlement, and democracy has impacted on infrastructure investment.

Cerra et al (2016) studied the infrastructural determinants and trends in Latin America and the Caribbean using a cross country comparison from 1990 to 2013. They found out that the determinants of infrastructural investments are public sector's budget constraint, private sector participation, interdependence among types of indicators, the level of income, the degree of urbanization, population density, fertility, rising financial depth, and the rule of law. In addition, infrastructure indicators in the region compare reasonably well with those in the group of emerging markets, particularly Asia.

Maria \& Bogado (2015) analysed cross-country determinants of infrastructure investment through PublicPrivate Partnership (PPP) in Latin America and the Caribbean considering 19 Latin American and Caribbean countries. Ordinary least squares (OLS) technique was used for the analysis. Empirical evidence from the study shows that the determinants of infrastructure through the PPP investment was explained through the regulatory framework and the public sector efficiency. They also found that market size significantly affects infrastructure investment.

Dao (2008) examined the determinants of infrastructure indicators in 27 developing countries using four samples of developing countries. The study was carried out using the OLS technique in multivariate linear regression. Evidence abounds that infrastructure indicator is linearly independent on the: share of 
public expenditure on pension in GDP, public spending for education as a percentage of government expenditure, the share of public spending for health on GDP, public savings as a percentage of GDP and civil service wages as a fraction of government spending. Importantly, only private spending for telecommunication is statistically significant cross country variations in the number of fixed and mobile telephone lines.

In Yoo \& Kim (2005) economic growth was found to impact on electricity generation in Indonesia by using data from 1971 to 2002 . Similar evidence was detected from the study conducted by Lean \& Symth (2010). It was established that income affects the electricity generated in Malaysia. Also, a similar study used a time series data of the economy of Bangladesh from the year 1973 to 2006 and had the same finding of income causing the generation of electricity in Bangladesh. In another study by Cerra et al. (2016) electricity generation capacity is quite responsive to economic and social factors, such as level of income, degree of urbanisation, population density, fertility, rising financial depth, higher debt burden, and private investment in the Latin America and the Caribbean.

The role of an institution was identified by Bergara (1997), who found that electricity generation capacity can be increased due to the existence of well-defined and reliable political institutions. The study conducted across 85 countries using OLS indicates a positive correlation between political institution credibility and electricity generation capacity. Also, Stern \& Cubbin (2006) investigated the impact of regulatory governance and privatisation on electricity infrastructure (electricity generation capacity). The study employed a fixed effect approach to analyse the effect of privatisation on electricity generation infrastructure among 28 developing. Empirical findings from the study revealed that minority and full privatisation have no significant effect on generation capacity. At 10 percent level of significance, the majority privatisation impact on electricity generation capacity.

From the review, the development of infrastructure is predicated upon social factors, economic factors, natural resources, as well as institutional factors. The emphasis in this paper is to examine the interaction of economic factors on the development of electricity generation infrastructure.

\section{Data And Methodology}

\subsection{Data}

The methodology for this study is based on econometric analysis. The dataset employed for the econometric analysis are collected from (i) Central Bank of Nigeria (CBN) Annual Statistical Bulletin for macroeconomic variables such as inflation rate, interest rate, total government expenditure and exchange rate, (ii) World Bank World Development Indicators (WDI) for urbanisation rate, private sector financial credit as share of GDP, gross fixed capital formation, and real GDP per capita, and (iii) International Energy Agency (IEA) for electricity generation capacity. Annual data spanning from 1980 to 2016 was used, this is so given that the econometrics analysis for a time series requires a substantial number of observations. Second, key reforms in the energy sector happened in the selected period. 
The following selected variables- electricity generation capacity, real GDP per capita, total public expenditure, private sector credit as a share of GDP, inflation rate, urbanization, interest rate, exchange rate, and real gross fixed capital formation- are consistent with the empirical literature. Tsoukis \& Miller (2003), Ghosh and Roy (2004). Cerra, et. al. (2016) and Cerra et.al. (2017) used several fiscal variables to measure the effect of government budget indicator infrastructure development. The authors also considered financial depth, measured by financial credit to the private sector (share of GDP) as a key component of infrastructure financing. The level of income (per capita income), degree of urbanisation, inflation rate, and private sector investment are other control variables considered by Cerra et.al. (2016). In this study, the interest rate is included as a financial sector policy variable that could attract or hinder infrastructure development. The inclusion of exchange rate is to capture the possibility of the instability that may arise from using the US dollar as a mechanism for benchmarking the domestic price of gas-topower, despite being regulated.

All variables are used based on their natural log form, except for transform variables like the inflation rate, exchange rate, interest rate, private sector financial credit as a share of GDP, and urbanisation rate.

\subsection{Methodology}

The model adopted in examining the determinants of electricity infrastructure development follows the model specification provided by Cerra et al. (2016). In their model, electricity generation infrastructure is considered as one of the critical infrastructures in an economy and is determined by government budget indicator, macroeconomic factors as well as institutional factors. The empirical model is defined in Eq. (1) as:

$$
\text { Gencap }_{t}=\partial_{0} P G D P_{t-1}+\partial_{1} \text { Fisc }_{t}+\partial_{2} X_{t}+u_{t}
$$

In the model specification, Gencapt is log of electricity generation capacity (electricity infrastructure), PGDP is log of real GDP per capita, Fisc is the government budget indicator (tax revenue, non-tax revenue, current expenditure, capital expenditure, primary balances as percent of GDP), $X$ are standard control variables electricity infrastructure development (private sector credit as a share of GDP, inflation rate, trade openness, urbanization, rule of law, and private sector investment), $t$ is the time index, and $u$ the error term.

In this paper, I modified the specification above to capture the peculiarity of the Nigerian economy with a particular interest in macroeconomic factors. As such the estimable model for investigating the determinants of electricity generation infrastructure is specified as:

$$
\text { Gencap }_{t}=\partial_{0} p G D P_{t}+\partial_{1} \text { EXPD }_{t}+\partial_{2} \text { Infl }_{t}+\text { Exc }_{t} \partial_{3}+\text { Pcre }_{t} \partial_{4}+\operatorname{Int} \partial_{5}+u_{t}
$$

$\partial 0, \partial 1$, and $\partial 4>0 ; \partial 2, \partial 3$, and $\partial 5<0$ 
Hence the total collected federal government capital expenditure will be used to reflect the government budget indicator, which is the fiscal effect. In selecting the control variables, key policy variables are selected to avoid the inclusion of many parameters in the model. Aside from these modifications, all variables remained as defined, except for the fact that the Nigerian electricity generation subsector has been privatised, which implies taking cognisance of the investment environment in terms of cost of funding measured by interest rate and the policy support for attracting new investment. Hence, the interest rate and price of natural gas to power are added as control variables among the drivers' electricity generation infrastructure.

The Autoregressive Distributed Lag (ARDL) was adopted for the estimation. The estimation technique allows for considering both short and long-run scenarios. The ARDL co-integration test popularly known as the bound test shows the long-run relationships and dynamic interactions between electricity infrastructure and the selected macroeconomic variables. The bound test is a simple technique because it allows a co-integration relationship to be estimated in an Ordinary Least Square (OLS) once the lag order of the model is identified. The long-run and short-run parameters of the models can be simultaneously estimated (Aregbeyen \& Ibrahim, 2012).

The conditional ARDL ( $p, q 1, \ldots q 5)$ and ( $p, q 1)$, the long-run model for Gencap will be estimated as specified in equation (4.3) below:

$$
\begin{aligned}
& \text { lnGencap }_{t}=\beta_{0}+\sum_{i=1}^{p} \beta_{1} \ln p G D P_{t-1}+\sum_{i=0}^{q 1} \beta_{2} E_{X P D_{t-1}}+\sum_{i=0}^{q 2} \beta_{3} \ln \operatorname{lnfl} l_{t-1}+ \\
& \sum_{i=0}^{q 3} \beta_{4} \ln \text { Exc }_{t-1}+\sum_{i=0}^{q 4} \beta_{5} \ln \text { Pcre }_{t-1}+\sum_{i=0}^{q 5} \beta_{7} \ln \ln t_{t-1} \mu_{t}
\end{aligned}
$$

The Error Correction Model (ECM), short-run model, representation of the series is specified as follows:

$$
\begin{aligned}
& \Delta \operatorname{lnGencap}_{t}=\beta_{0}+\sum_{i=1}^{p} \beta_{1} \Delta \ln p G D P_{t-1}+\sum_{i=0}^{q 1} \beta_{2} \Delta \ln E X P D_{t-1}+ \\
& \sum_{i=0}^{q 2} \beta_{3} \Delta \operatorname{lnInfl}+\sum_{i=0}^{q 3} \beta_{4} \Delta \ln E x c_{t-1}+\sum_{i=0}^{q 4} \beta_{5} \Delta \ln P \operatorname{cre}_{t-1}+\sum_{i=0}^{q 5} \beta_{7} \Delta \operatorname{lnInt}_{t-1} \mu_{t}
\end{aligned}
$$

In performing the estimation in Eqs. (3) and (4), the selected variables are subjected to a time series statistical check, the unit root test. The unit root test is based on the Augmented Dickey-Fuller (ADF) and Philips Perron (PP). This is to enhance reliable inferences for policy decisions.

\section{Results And Discussion}

The discussion in this section is on the empirical findings, specifically, on the: time series properties of the variables, and the short and long-run determinants of electricity infrastructure in Nigeria.

\subsection{Unit Root Result}


The ARDL bounds test requires that the order of integration of all variables do not exceed I (1), given that presence of I (2) among the considered variables may likely result in spurious results. In a presence of I(2) variables, the computed F-statistic provided by ARDL bound test valid, for the ARDL bound test is based on the assumption that the variables are either I(0), I(1) or a mixture of both (Quattara, 2004; Pesaran et al. 2001). Augmented Dickey-Fuller and Philip Perron (PP) unit root tests were employed to validate the order of integration of the employed variables. One of the variables was found to be of order zero (per capita income (GDP), while the other variables were integrated of order one I (1) (Table 1).

\subsection{Bound Test for Cointegration}

Testing for cointegration requires conducting an ARDL Bounding test that enables one to ascertain whether or not long-run relationship exists among the variables of interest. Specifically, the ARDL bounding test was implemented using equation (4.3) for electricity generation capacity. Given the short data span, the maximum lag order of 2 was imposed for the dependent variables while that of the independent variables was restricted to a maximum lag order of 1 .

The calculated F-statistics of GENCAP Model at 3.779 is higher than the upper critical value for I(1) Bound at $5 \%$ level (Appendix 1). Thus, the null hypothesis of no cointegration was rejected, suggesting the existence of a long-run relationship in the model. This implies that both the long run and the short run model can be considered for GENCAP model.

Having established the existence of a long-run cointegrating relationship in the estimated model, the ARDL specification $(2,1,0,0,0,0,0,1,1)$ for GENCAP model. The model was estimated based on an assumption of a linear trend. The selection of the estimated model was based on the Schwarz criterion model selection criteria.

\subsection{Long-run and Short-run Determinants of Electricity Generation Infrastructure}

The main purpose of estimating the electricity generation capacity model is to determine if there is any relationship between some selected macroeconomic aggregates and electricity generation infrastructure and the degree of this relationship. The estimated long-run and short-run coefficients for the generation capacity model are presented in Tables 2 and Table 3 respectively.

The estimated coefficients of the long run relationship presented in Table 2 show a positive relationship between inflation rate (INFL), interest rate (INT) and electricity generation capacity; meaning that inflation rate and interest rate boost electricity generation capacity in Nigeria. Unlike the interest rate, the coefficient of the inflation rate is statistically significant. The outcome of the two variables is counterintuitive, as a negative relationship is expected. Financial credit to the private sector (CREDP), total public expenditure (EXPD), real per capita income (Pgdp), real gross fixed capital formation, (RGFCF), urbanization (URB), and exchange rate (EXCR) adversely affect the development of electricity generation capacity. These results are contrary to expectation, except for exchange rate. An increase in the exchange rate, that is depreciation of the domestic currency, which increases the price burden of gas- 
to-power, dampens development on electricity generation infrastructure. Apart from for private sector credit, and the real gross fixed capital formation, all other variables are statistically significant.

\section{2: Diagnostic and Stability Tests}

The test for serial correlation was conducted based on the LM test, with the null hypothesis that the residuals are serially uncorrelated. The F-Statistic p-value of 0.6721 indicates the acceptance of this null, thus, the residuals are serially uncorrelated (Appendix 2). The stability condition of the error correction model was tested based on the Cumulative Sum of Recursive Residuals (CUSUM), and the Cumulative Sum of Square Recursive Residuals (CUSUUM). The plots fall within the critical bands, hence, Nigeria's generation capacity short-run model is structurally stable (Appendix 3 and 4).

\section{Conclusion}

The paper investigates the determinants of electricity generating infrastructure in Nigeria for the period 1980 to 2017. Electricity generation capacity was used as an indicator for electricity infrastructure development. Based on the empirical literature, some selected macroeconomic aggregates are also employed, these are inflation rate, total government expenditure, interest rate, private sector financial credit, exchange rate, real GDP per capita, real gross fixed capital formation, and the rate of urbanisation. The following key findings emerged. A positive relationship exists between inflation rate, interest rate, and electricity generation capacity. These factors are not critical to the development of electricity infrastructure, considering the fact that their estimated coefficient is counterintuitive and not significant. Financial credit to the private sector and real gross fixed capital formation negatively impact on electricity infrastructural expansion. This show that the country's financial depth is not strong or attractive enough to stimulate the kind of investment needed in building generating assets. Investment in electricity generation assets is capital intensive, which should be matched with adequate private sector financing. Total public expenditure, real per capita income, urbanization, and exchange rate were established; to adversely impede the development of generation infrastructure significantly. This suggests that an increase in government expenditure, in terms of power sector subsidy and subventions, does not engender an improvement in electricity generation capacity. Likewise, the domestic currency depreciation increases the burden of price of gas-to-power by impacted on the regulated domestic price of gas-topower that is priced at a US dollar. Thus, rather than incentivising investment in electricity generation, the prevailing market exchange rate alters the benefits that could spur development in electricity generation value chain. If the power sector subsidy will remain and achieve its objective, strategies that will lead to sustaining exchange rate stability should be promoted. Presently, the growing urbanisation in Nigeria does not propel an expansion in generation capacity, possibly due to the low standard of living, which impinges on individuals' ability to pay for electricity demand. Based on the estimate, every one million population require $1000 \mathrm{MW}$ of electricity to function in modern-day society, implying that Nigeria needs $180,000 \mathrm{MW}$ of electricity capacity. The realisation of this is hinged on the large scale electricity infrastructure investment enabled, in part, by the favourable macroeconomic environment. 
Further research should explore ways to be which infrastructure development can be enhanced in the distribution value chain of the power sector. In its present state, the distribution segment of the power sector is overwhelmed in a myriad of challenges undermining the performance of the sub-sector even after the full privatisation that kicked-up in 2013. These problems have culminated into high transmission and distribution losses, which need to be addressed through requisite investment financing. This recommendation is made to ensure that expansion in generating capacity is matched with equal distribution assets that will boost greater electricity access in the country.

\section{Declarations}

\section{Data Availability}

Data is available on request.

\section{Acknowledgements}

Not applicable.

\section{Funding}

None.

\section{Affiliation}

Economics and Business Policy Department, Nigerian Institute of Social and Economic Research (NISER), PMB 5, UI Post Office, Ojoo, Oyo Road, Ibadan, Oyo State, Nigeria.

\section{Contributor}

The author read and approved the manuscript

\section{Corresponding Author}

Correspondence to lyabo Olanrele

\section{Ethics Declaration}

The author declares no competing interest

\section{References}

1. Agenor, P., Neanidis, K. C., (2015). Innovation, public capital and growth. J of Macroeconomics, Vol. 44(c), Pages 252-275.

2. Aregbeyen, O., Ibrahim T.M., (2012). Testing the revenue and expenditure nexus in Nigeria. European Journal of Soc. Sci, vol. 27, No. 3 pp 374-380. 
3. Aschauer, D. A.,(1988). Public capital and economic growth: issues of quantity, finance, and efficiency. Levy Economics Institute Working Paper No. 233.

4. Bergara, M., (1997). Network access pricing and "Light Handed" regulation: a comparative institutional analysis, U.C. Berkeley, Mimeo.

5. Calderon, C., Serven, L., (2014). Infrastructure, growth, and inequality: an overview. Policy Research Working Paper; No. 7034. World Bank Group, Washington, DC.

6. Calderon, A., Serven, L., (2010). Infrastructure in Latin America, May 1, 2010, World Bank Policy Research Working Paper, No. 5317.

7. Cerra V, Cuevas A, Goes C, et al. (2017). Determinants of Infrastructure and Its Financing. Emerging Economy Studies.3(2):113-126. doi:10.1177/2394901517730739

8. Cerra, V., Cuevas, A., Góes, C., Karpowicz, I., Matheson, T., Samaké, I., Vtyurina, S. (2016). Highways to Heaven: Infrastructure Determinants and Trends in Latin America and the Caribbean. IMF Working Papers, 16(185), 1. https://doi.org/10.5089/9781475536744.001

9. Dao, Minh. (2008). The Determinants of Infrastructure Development in Developing Countries. J Stud in Econ and Econometrics. 32. 10.1080/10800379.2008.12106456.

10. Kodongo, O., Ojah, K. (2016). Does infrastructure really explain economic growth in Sub-Saharan Africa? Review of Development Finance, 6(2), 105125. https://doi.org/10.1016/j.rdf.2016.12.001

11. Lean, H.H., Smyth, R., 2010. C02 emissions, electricity consumption and output in ASEAN'. Applied Energy, 87, 1858-1864.

12. Maria, C., Bagado, M. (2015). Determinants of infrastructure investment through Public-Private Partnership in Latin America and the Caribbean. https://www.stp.gov.py/v1/wpcontent/uploads/2017/04/Final-Thesis.pdf

13. Martinkus, B., Lukasericius, K., (2008). Investment, environment of Lithuanian resorts: researching national and local factors in the Palanga case. Tans in Bus and Econ 7(2), 67-83.

14. Mentolio, D. Sole-Olle, A., (2009). Road investment and regional productivity growth: the effect of vehicle intensity and congestion. Papers in Regional Science (88), 99-118.

15. Palei, T. (2015). Assessing the Impact of Infrastructure on Economic Growth and Global Competitiveness. Procedia Economics and Finance, 23(15), 168-175. https://doi.org/10.1016/s2212-5671(15)00322-6

16. PEPRAH, D. A. (2015). Determinants of Electricity Generation: the Case of Selected Sub-Saharan African Countries. By in Partial Fulfilment of the Award of Master of (Issue July).

17. Pesaran M.H., Shin Y., Smith R.J., (2001). Bounds testing approaches to the analysis of level relationships. J Applied Econometrics, Vol.16, pp. 289-326.

18. Power Sector Watch. (2021). Nigeria 's Electricity Supply Industry Highlights. February, 1-3.

19. Quattara, B., (2004). Modelling the long run determinants of private investment in Senegal. The School of Economics Discussion Paper Series 0413, Economics, The University of Manchester. 
20. Sambo, A.S., (2008). Matching supply with demand. National Workshop on the Participation of state governments in the power sector:, Ladi Kwali Hall, Sheraton Hotel \& Towers, Abuja.

21. Snieska, V., Draksaite, A., (2007). The role of knowledge process outsourcing in creating national competitiveness in global economy. Inzinerine Ekonomimka-Engineering Economics (3), 35-41.

22. Stern, J., Cubbin, John. (2006). The Impact of Regulatory Governance and Privatization on Electricity Industry Generation Capacity in Developing Economies. World Bank Economic Review. 20. 115-141. 10.1093/wber/lhj004.

23. Storeygard, A., Jedwab, R. (2017). Economic and Political Factors in Infrastructure Investment: Evidence from Railroads and Roads in Africa 1960 - 2015. 202.

24. Ghosh, S., Roy, U. (2004). Fiscal policy, long-run growth, and welfare in a stock-flow model of public goods. Canadian Journal of Economics. Vol. 37(3), Pages 742-756.

25. Tatyana P., (2015). Assessing the impact of infrastructure on economic growth and global competitiveness. Procedia Economics and Finance, Vol. 23, pp. 168-175

26. Tsoukis, C., Miller, N., (2003). Public services and endogenous growth. J Policy Modelling 25, 297-307.

27. Ubi, P. Effiom, L, Okon, E. Oduneka, A. (2012). An Econometric Analysis of the Determinants of Electricity Supply in Nigeria. International Journal of Business Administration. 3. 10.5430/ijba.v3n4p72.

\section{Tables}

\section{Table 1: Unit Root Test Result}




\begin{tabular}{|c|c|c|c|c|c|c|}
\hline & \multicolumn{2}{|c|}{ Augmented Dickey Fuller } & & \multicolumn{2}{|c|}{ Phillips Perron } & \\
\hline Variable & Intercept & $\begin{array}{l}\text { Intercept and } \\
\text { Trend }\end{array}$ & Remark & Intercept & $\begin{array}{l}\text { Intercept and } \\
\text { Trend }\end{array}$ & Remark \\
\hline GENCAP & -7.095 & -8.281 & $\mathrm{I}(1)$ & -7.376 & -9.729 & $\mathrm{I}(1)$ \\
\hline$I N T$ & -5.904 & -6.144 & $\mathrm{I}(1)$ & -9.487 & -9.919 & $\mathrm{I}(1)$ \\
\hline$I N F L$ & -5.581 & -5.486 & $\mathrm{I}(1)$ & -10.896 & -10.590 & $\mathrm{I}(1)$ \\
\hline PCRED & -4.774 & -4.807 & $\mathrm{I}(1)$ & -15.35 & -16.333 & $\mathrm{I}(1)$ \\
\hline$E X P D$ & -6.079 & --7.128 & $\mathrm{I}(1)$ & -6.961 & -7.073 & $\mathrm{I}(1)$ \\
\hline$E X C$ & -8.339 & -8.359 & $1(1)$ & -3.703 & -4.043 & $\mathrm{I}(1)$ \\
\hline$p G D P$ & -4.851 & -5.057 & $\mathrm{I}(0)$ & -4.847 & -5.062 & $\mathrm{I}(0)$ \\
\hline$U R B$ & -2.816479 & -5.416306 & $\mathrm{I}(1)$ & -2.689943 & -9.063364 & $\mathrm{I}(1)$ \\
\hline$R G F C F$ & -4.777 & -4.933 & $\mathrm{I}(1)$ & -5.935 & -5.581 & $\mathrm{I}(1)$ \\
\hline
\end{tabular}

Table 2: Estimated Long Run Coefficients for the Electricity Generation Capacity Model

\begin{tabular}{|l|l|l|l|l|}
\hline $\begin{array}{l}\text { Dependent Variable: GENCAP } \\
\text { Selected Model; ARDL }(2,1,0,0,0,0,0,1,1)\end{array}$ \\
\hline Variable & Coefficient & Std.Error & t-Statistic & Prob. \\
\hline INFL & 0.001 & 0.000 & 2.685 & 0.014 \\
\hline INT & 0.001 & 0.001 & 1.084 & 0.291 \\
\hline CREDP & -0.000 & 0.013 & -0.005 & 0.996 \\
\hline EXPD & --0.055 & 0.016 & -3.484 & 0.002 \\
\hline Pgdp & -0.069 & 0.039 & -1.792 & 0.088 \\
\hline RGFCF & -0.015 & 0.022 & -0.687 & 0.500 \\
\hline URB & -0.079 & 0.016 & -5.002 & 0.000 \\
\hline EXCR & -0.000 & 0.000 & -2.999 & 0.007 \\
\hline$C$ & 10.263 & 1.006 & 10.205 & 0.000 \\
\hline$@ T R E N D$ & 0.044 & 0.003 & 13.902 & 0.000 \\
\hline
\end{tabular}

Table 3: Estimated Short Run Coefficients for the Electricity Generation Capacity Model 


\begin{tabular}{|l|l|l|l|l|}
\hline $\begin{array}{l}\text { Dependent Variable: GENCAP } \\
\text { Selected Model; ARDL }(2,1,0,0,0,0,1,1)\end{array}$ \\
\hline Variable & Coefficient & Std.Error & t-Statistic & Prob. \\
\hline$D($ GENCAP(-1)) & 0.376 & 0.199 & 1.889 & 0.074 \\
\hline$D($ INFL $)$ & 0.000 & 0.000 & 1.545 & 0.138 \\
\hline$D(I N T)$ & 0.001 & 0.001 & 1.142 & 0.267 \\
\hline$D(C R E D P)$ & -0.000 & 0.020 & -0.005 & 0.996 \\
\hline$D(E X P D)$ & -0.083 & 0.022 & -3.707 & 0.001 \\
\hline$D(R G D P C)$ & -0.105 & 0.068 & -1.541 & 0.139 \\
\hline$D(R G F C F)$ & -0.023 & 0.034 & -0.675 & 0.507 \\
\hline$D(U R B)$ & -0.271 & 0.078 & -3.467 & 0.002 \\
\hline$D(E X C R)$ & 0.000 & 0.000 & 0.079 & 0.937 \\
\hline$E C M(-1)$ & -0.067 & 0.012 & -5.471 & 0.000 \\
\hline
\end{tabular}

Figures

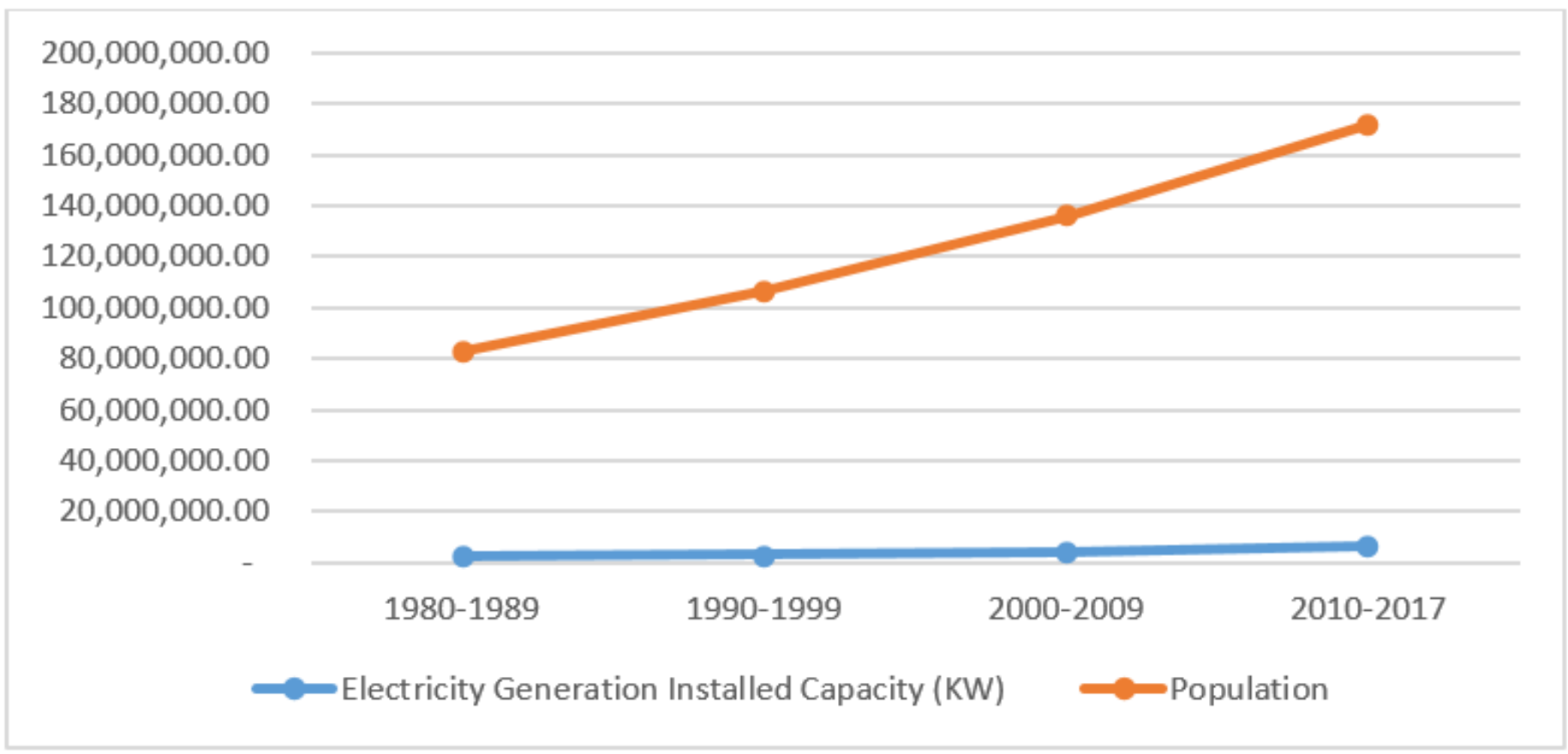

\section{Figure 1}

Electricity Generation Installed Capacity and Population Source: WDI, 2018 


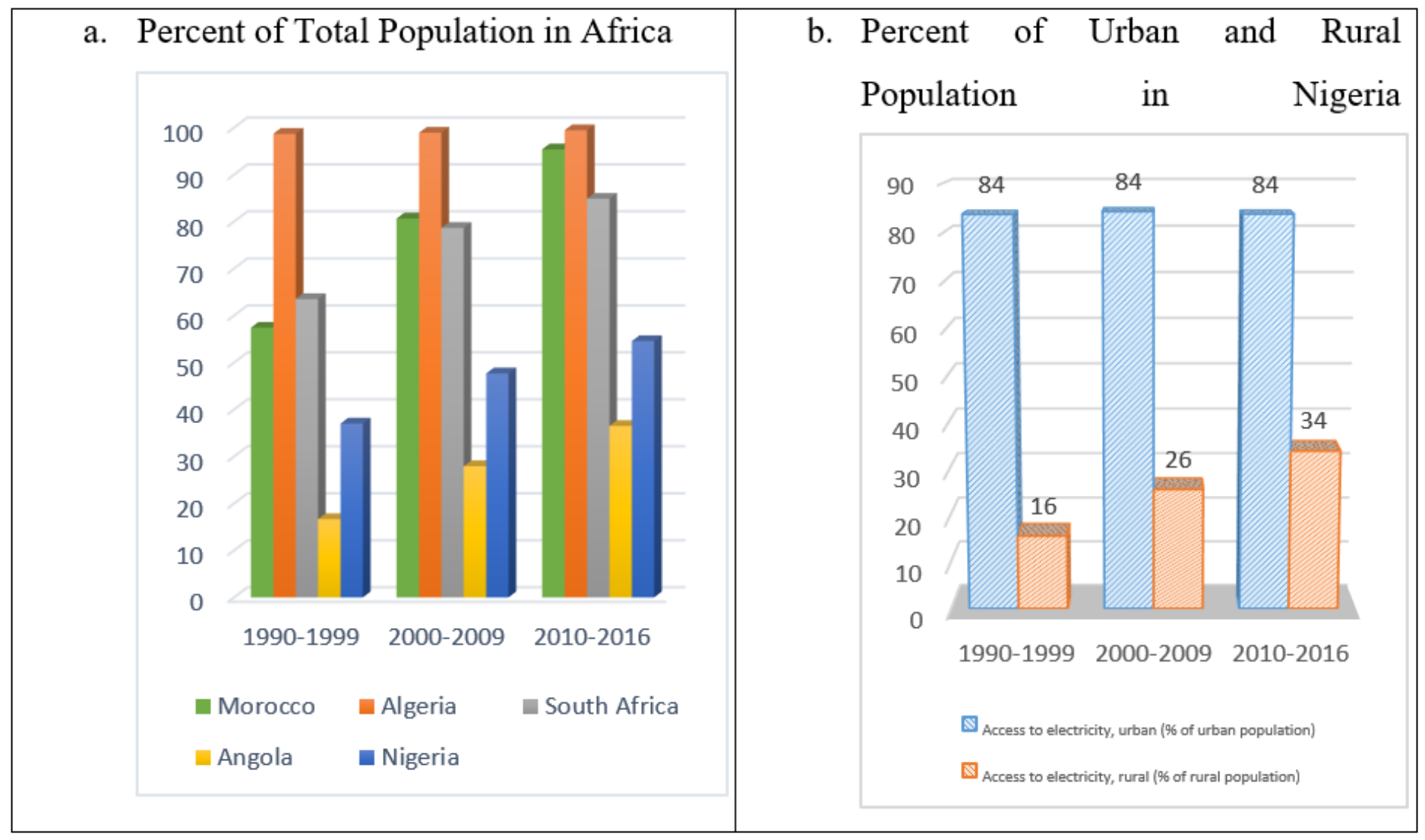

Figure 2

Access to Electricity in Africa Source: WDI, 2018

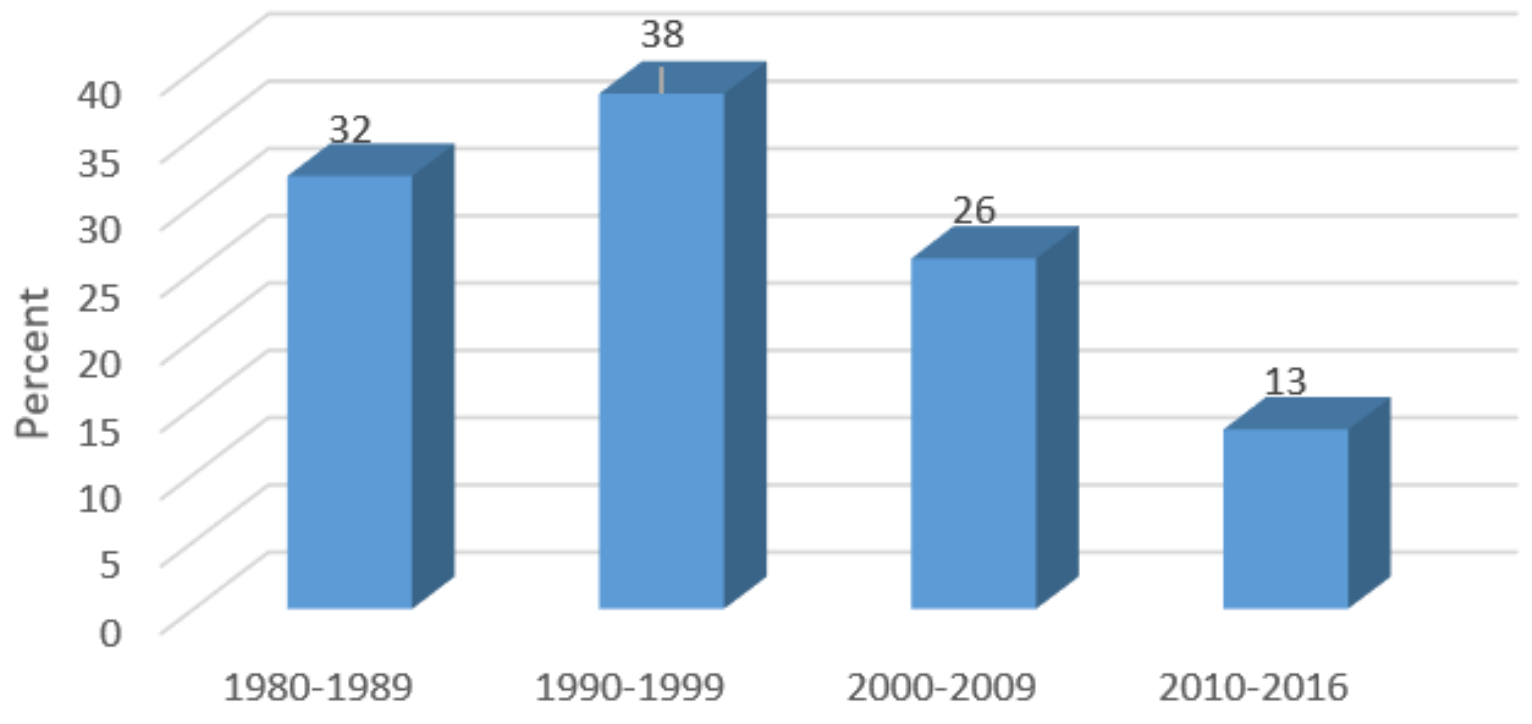

Figure 3 
Electricity Power Transmission and Distribution Losses in Nigeria (\% of Output) Source: WDI, 2018

\section{Supplementary Files}

This is a list of supplementary files associated with this preprint. Click to download.

- Appendix.docx 